Jenis dan Bentuk Metafora dalam Kisdap "Julak Ahim " (Siti Jamzaroh)

\title{
JENIS DAN BENTUK METAFORA DALAM KISDAP “JULAK AHIM" KARYA JAMAL T. SURYANATA
}

\author{
The Types and Forms of Metaphors in the Kisdap "Julak Ahim" by Jamal T. Suryanata
}

\author{
Siti Jamzaroh \\ Balai Bahasa Kalimantan Selatan \\ Jalan A. Yani km 32,2 Loktabat, Banjarbaru, Kalimantan Selatan 70712, \\ pos- email: siti.jamzaroh0107@gmail.com
}

\begin{abstract}
Abstrak: Penelitian ini bertujuan untuk mengetahui 1) jenis metafora Kisdap "Julak Ahim", dan (2) fungsi metafora dalam yang terdapat dalam kisdap "Julak Ahim". Metode yang digunakan dalam penelitian ini adalah deskriptif kualitatif. Pengumpulan data dilakukan dengan teknik baca dan teknik catat. Selanjutnya data diklasifikasikan berdasarkan ciri-ciri metaforis yang diperlihatkan. Analisis data dilakukan dengan mengkontraskan data ungkapan yang digunakan dengan kiasannya. Hasil yang ditemukan dalam penelitian ini adalah 1) Jenis metafora yang ditemukan berdasarkan 1) unsur pembentuknya dalam kisdap "Julak Ahim" adalah a) metafora kehewanan (animal metaphoric) (2); b) metafora sinestesia (synesthesia metaphoric) (1); c) metafora ke-manusia-an (antropomorfemik metaphoric) (2); dan d) metafora konkret-abstrak (concrete-abstract metaphoric) (2); 2) berdasarkan struktur pembentuknya, terdapat a) metafora nominatif subjektif dan komplementatif dan b) metafora kalimatif.
\end{abstract}

Kata kunci: kisdap, sinestesi, ciri-ciri metaforis

Abstract: This research is aimed to find out 1) to know the type of metaphor of Kisdap "Julak Ahim" (2) to describe the metaphoric function in that contained in Kisdap "Julak Ahim" The method used in this research is qualitative descriptive. Data collection is done by reading technique and record technique. Furthermore, the data are classified based on the metaphorical characteristics shown. Data analysis is done by contrasting the expression data used with the metaphor. The results found are: 1) The type of metaphor found based on 1.1) its constituent elements in kisdap "Julak Ahim" is a) the animal metaphor (2); b) the synesthesia metaphor (1); c) anthropomorphic metaphor (2); and d) concrete-abstract metaphor (2); 1.2) based on its structure, there are a) subjective and complementary nominative metaphors and b) sentence metaphors.

Keywords: kisdap, synesthesia, metaphorical characteristics

\section{PENDAHULUAN}

Setiap etnik memiliki cara pandang yang berbeda dalam memahami kehidupan dibandingkan dengan etnik yang lain. Karena pengalaman yang hidup yang didapat juga berbeda. Pengalaman hidup yang dikristalkan dalam bentuk ungkapan-ungkapan muncul dalam percakapan sehari-hari. Salah satunya masyarakat yang masih memelihara tradisi bertutur dengan menggunakan ungkapan atau peribahasa adalah masyarakat Banjar. 
Undas Vol 14, No. 1, Juni 2018 : hlm. 48--57

Masyarakat Banjar seperti halnya masyarakat lainnya, memiliki budaya atau kultur yang membedakannya dengan masyarakat lain di Indonesia. Perkembangan sosial yang terjadi di seluruh negeri tentu saja membawa dampak sosial bagi masyarakat Banjar pula, sehingga kekhawatiran akan lenyapnya warisan budaya menjadi dorongan yang kuat pagi para sastrawan untuk berupaya menanamkan warisan kearifan lokal tersebut dalam bentuk fiksi. Penulis atau sastrawan mengiringi perubahan sosial kemasyarakatan tersebut dengan mengabadikannya dalam bentuk ungkapan dan peribahasa pada cerpen atau kisdap (kisah handap) Banjar. Meskipun ungkapan-ungkapan yang berisi nasihat-nasihat tersebut sudah mulai dianggap usang, hal tersebut tidaklah dirasakan oleh masyarakat pembaca, karena kemasan dalam bentuk fiksi baik cerpen dan novel memberikan hiburan tersendiri. Pembaca seakan-akan mengalaminya dalam kehidupan nyata.

Kisdap atau cerita pendek dalam bahasa Banjar merupakan salah satu karya sastrawan Banjar. Selain kisdap, ada kumpulan puisi atau antologi puisi, novel dan sebagainya, baik dalam bahasa Indonesia maupun bahasa Banjar. Kisdap Banjar karya Jamat T. Suryanata ini diberi judul "Galuh" yang berisi cerita pendek, salah satunya adalah kisah 'Si Julak Ahim". Di dalamnya terdapat petuah atau ungkapan-ungkapan lama atau ungkapan bahari. Ungkapanungkapan tersebut dilukiskan atau dikiaskan dengan bahasa figuratif, salah satunya adalah metafora.

Studi kebahasaan tentang metafora telah dilakukan sejak zaman Aristoteles (384-322 SM) yang kemudian dilanjutkan oleh beberapa ahli bahasa seperti Quintillian dalam Levin, (1977) seperti yang dikutip Wahab (1995:73)

Ariestoteles mendefinisikan metafora sebagai ungkapan kebahasaan untuk menyatakan hal yang bersifat umum untuk hal yang bersifat umum, dan bersifat khusus untuk hal yang bersifat khusus, atau dengan jalan analogi (Poetics, 1457 B, dalam Wahab (1995). Selanjutnya Quintillian mengatakan bahwa metafora itu adalah ungkapan kebahasaan untuk mengatakan sesuatu yang hidup untuk sesuatu yang lain juga hidup, yang hidup untuk sesuatu yang mati, sesuatu yang mati untuk sesuau yang hidup, dan sesuatu yang mati untuk sesuatu yang mati ( hlm. 72) Sedangkan Kridalaksana (2008) menyatakan bahwa metafora adalah pemakaian kata atau ungkapan lain untuk obyek atau konsep lain berda-sarkan kias atau persamaan: mis. Kaki gunung, kaki meja berdasarkan kias kaki manusia (hlm. 152).

Definisi metafora secara teknis dikemukakan oleh Lakoff dan Johns (1980: 5) dalam Rahyono (2012: 189). Mereka menyatakan bahwa "The essence of the metaphor is understanding and experiencing one kind of thing in term and another" Para pecinta memahami dan memiliki pengalaman mendalam terhadap segala objek yang dihadapinya dalam kehidupan sehari-hari. Apa yang dipahami dan diungkapkan dengan menggunakan kata-katanya yang lain berdasarkan konsep kebahasaan yang dimilikinya.

Bahasa figuratif khususnya metafora banyak dimanfaatkan penlis untuk mengiaskan atau melambangkan peristiwa sosial dalam bentuk ungkapan dan peribahasa.

Lakoff (1987) berpendapat seperti yang dikutip oleh Cruse (2000:205-206) 
Undas Vol 14, No. 1, Juni 2018 : hlm. 48--64

mengemukakan tiga komponen konseptual metafora, yakni tenor atau target, vehicle, dan grounded. Dari metafora konseptual dikembangkan menjadi metafora kognitif. Taylor dalam Prayuda (2013) menjelaskan tenor atau target domain (pembanding) adalah konsep objek yang dideskripsikan, dibicarakan, dikiaskan, dilambangkan, atau dibandingkan. Target domain disebut juga resiptor. Vehicle atau source domain (pembanding) merupakan konsep yang mendeskripsikan atau mengkiaskan atau melambangkan tenor atau target domain. Source domain disebut juga donator. Dalam arti ini, vehicle atau source domain adalah lam-bang atau kiasan itu sendiri. Ground (sense atau persamaan) adalah relasi persamaan objektif seperti bentuk, tempat sifat, atau kombinasi di antaranya, persamaan konsep, fungsi, dan persamaan budaya (hlm. 375).

Penelitian mengenai ungkapan bahasa Banjar pernah dilakukan oleh Eka Suryatin yang berjudul Macam-Macam Flora dan Fauna dalam Ungkapan Bahasa Banjar (Undas, 2013). Penelitian tersebut mengungkapkan jenis-jenis flora dan fauna yang dipergunakan sebagai lambang perbandingan. Penelitian selanjutnya dilakukan oleh Siti Jamzaroh, Wahdani, Siti Alfa, dan Laila yang berjudul Nilai-nilai Kearifan Lokal dalam Ungkapan Bahasa Banjar (Salingka, 2017) dan Srinengsih (2016) yang berjudul Makna Idiomatik dalam Ungkapan bahasa Banjar. Namun, kajian tentang metafora belum dilakukan secara mendalam.

Penelitian metafora dipandang dari segi ruang persepsi manusia terhadap ruang semantik, khususnya mengenai dalam bahasa Banjar belum pernah dilakukan oleh linguis. Data penelitian ini adalah ungkapan yang terdapat dalam kisdap "Julak Ahim" dalam kumpulan cerpen Galuh: Sakindit Kisdap Banjar karya Jamal. T Suryanata.

\section{KERANGKA TEORI}

\subsection{Jenis Metafora}

Metafora dapat diklasifikasikan berdasarkan (1) unsur pembentuknya, dan (2) struktur sintaksisnya.

Ullman (1962) dalam Subroto (2017) membedakan jenis metafora atas empat kategori, yakni (1) meta-fora antropomorfik (anthropomorphic metaphoric), (2) metafora kehewanan (animal metaphoric), (3) metafora dari konkret ke abstrak (from concrete to abstract), (4) metafora sinestesia (sinestesia meta-phoric). Penjelasannya adalah sebagai berikut (hlm. 131-132)

\subsubsection{Metafora antromorfomik (anthro-} pomorphic metaphoric),

Penciptaan metafora itu bertolak dari tubuh manusia atau dari nilai/makna dan nafsu-nafsu /kesenangan yang dimiliki oleh manusia. Dari situ kemudian dialihkan /ditransfer untuk benda-benda tak bernyawa sehingga benda-benda atau objek yang sebenarnya takhidup atau tak bernyawa itu dipersepsi atau dipahami sebagai hidup atau bernyawa.

\subsubsection{Metafora kehewanan (animal meta-} phoric)

Jenis ini menggunakan bina-tang atau bagian tubuh binatang atau sesuatu yang berkaitan dengan binatang untuk pencitraan sesuatu yang lain. Pada umumnya didasarkan pada kemiripan bentuk yang cukup jelas sehingga kurang menghasilkan karya ekspresivitas yang kuat.

\subsubsection{Metafora dari konkret ke abastrak} (from concrete to abstract) 
Undas Vol 14, No. 1, Juni 2018 : hlm. 48--57

Jenis ini dapat dinyatakan sebagai kebalikan dari hal-hal yang abstrak atau samar-samar diperlakukan sebagai sesuatu yang bernyawa sehingga dapat berbuat secara konkret atau bernyawa.

2.1.4 Metafora sinestesia (sinestesia metaphoric).

Jenis ini pada dasarnya suatu pemindahan atau pengalihan dari pengalaman yang satu ke pengalaman yang lain, atau dari tanggapan yang satu ke tanggapan yang lain. Misalnya pengalihan dari sesuatu yang bersifat suara ke sesuatu lain ke wilayah penglihatan, atau dari wilayah yang berkaitan dengan perabaan ke sesuatu yang bersifat suara. Contoh suara adalah sesuatu yang didengar diperla-kukan sebagai sesuatu yang dilihat, misalnya senyumnya yang manis, pahit geirnya kehidupan, matanya sejuk menatapku, dan lain-lain

\subsection{Bentuk Metafora}

Wahab (1995) mengklasifikasikan metafora berdasarkan strukturnya menjadi (1) metafora nominatif, (2) metafora predikatif, dan (3) metafora kalimatif. Metafora nominatif, lambang kiasnya hanya terdapat pada subjek kalimat. Karena posisi nomina kalimat berbeda, metafora nominatif terbagi menjadi metafora nominatif subjektif dan metafora nominatif objektif. Keduanya lazim disebut metafora nominatif subjektif dan metafora nominatif komplementatif. (hlm. 72)

Contoh:

1. [Angin] sama sekali tidak singgah. (Slamet Sukirmanto, 1983: "Tunggu" dalam Horizon/XXI/225) (Wahab,1995: )

Dalam sanjak tersebut, Wahab menjelaskan bahwa [angin] dipakai sebagai subjek untuk meng-kiaskan manusia pembawa berita. Sementara komponen lain lama tidak singgah sebagai predikat tidak dikiaskan.

2. Aku minta dibikinkan jembatan cahaya. (Ismet Nasir, dalam Linus Suryadi AG (ed), 1987.Tonggak, 4:59) dalam Wahab (1995)

Selanjutnya, kelompok kata jembatan cinta berfungsi sebagai komplemen kalimat "Aku minta dibikinkan..." Jembatan cahaya adalah kata-kata kias yang maknanya sebenarnya ialah 'jalan yang terang'. Jembatan cahaya merupakan contoh metafora nominatif komplementatif

3. Suara aneh terbaring di sini .(T.Mulia Lubis, dalam Tonggak, 4:15)

Masih dalam sanjak yang sama, kata terbaring yang merupakan predikat subjek kalimat "Suara aneh...", merupakan predikat, dan yang cocok adalah mamalia (hlm. 72--73)

\section{METODE PENELITIAN}

Kridalaksana (2008) menyata-kan bahwa metode adalah 1) sara mendekati, mengamati, menganalisis, dan menjelaskan suatu fenomen; 2) sikap sekelompok sarjana terhadap bahasa atau linguistik, mis. metode preskreptif, komparatif, dsb.; 3) pelbagai teknik untuk menetapkan dan mengukur ciri bahasa, mis. penelitian lapangan, eksperimen dalam laboratorium, dsb.; dan 4) prinsip-prinsip dan praktekpraktek pengajaran bahasa, mis. metode langsung, metode gramatika terjemahan, dsb. (hlm. 153). Metode yang digunakan dalam penelitian ini adalah deskriptif kualitatif. Metode ini digunakan berdasarkan data berupa fakta yang ditemukan dalam cerpen "Julak Ahim" 
Undas Vol 14, No. 1, Juni 2018 : hlm. 48--64

pada Kisdap Banjar, Jamal, T. Suryanata. Pengumpulan data dilakukan dengan teknik baca dan teknik catat. Selanjutnya data diklasifikasikan berdasarkan ciri-ciri metaforis yang diperlihatkan. Analisis data dilakukan dengan mengkontraskan data ungkapan yang digunakan dengan kiasannya.

\section{ANALISIS DAN PEMBAHASAN}

Dalam bahasa Banjar, ditemu-kan ungkapan-ungkapan yang mengandung metafora dalam pembicaraan santai di warung kopi. Peng-gunaan ungkapan-ungkapan yang mengandung metafora membuat perbincangan yang terjadi dalam sebuah warung kopi menjadi semakin hangat. Berikut ini pembahasan ungkapan-ungkapan tersebut.

\subsection{Jenis Metafora}

Jenis Metafora Berdasarkan Unsur Pembentuknya

4.1.1 Metafora kehewanan (animal metaphoric)

Konteks 1:

Gaguduhan pagunan liwar panas, jangan pang balalu diungap haja. [Nang kaya limbah disasahi hadangan]haa lagi Ilat andika ya . asal ladar kapanasan. (hal 5)

‘Pisang goreng memang terlalu panas, janganlah terus ditelan aja. Seperti habis dikejar banteng. lagi lihat lidah anda, asal kepanasan'(hal 5)

Dalam ungkapan "Nang kaya limbah disasahi hadangan 'dikejar banteng/ kerbau liar' merupakan kias-an dari kondisi yang disebutkan pada kalimat "Gaguduhan pagunan liwar panas, jangan pang balalu diungap haja". Gerakan 'mengeluarkan napas dari mulut kepanasan' itulah dikiaskan dengan ungkapan nang kaya disasahi hadangan. Ungkapan tersebut meman-faatkan hewan sebagai lambang kiasnya.

Konteks 2

"Hi ih, tahi giling tuh siapa nang mangambinginya? Damintu kalu?" ujar Julak Ahim mamagat pandiran Amang Kbat. (hlm. 9)

'Hi ih, tahi giling siapa yang jadi kambingnya?. Begitu kan? Kata Julak Ahim memotong omongan Amang Kbat. (hlm. 9)

Dalam pernyataan "Hi ih, tahi giling tuh siapa nang mangambinginya? Damintu kalu?" ujar Julak Ahim mamagat pandiran Amang Kbat . (hal 9) terdapat ungkapan tahi giling 'tahi berbentuk seperti digiling', dan siapa yang mangambingi 'siapa yang bersikap seperti seekor kambing'. Tahi giling merupakan penggambaran kias bentuk 'kotoran seolah-olah sengaja dibentuk layaknya membuat roti', dan siapa nang mangambingi merupakan perbandingan kias yang bermakna 'perbuatan manusia yang hanya pantas dilakukan seekor kambing'.

Konteks 3

Kada lawas tadangaran bunyi barucau di wawarung. Pandir maniti kahulu ka hili kada kasintakan hinak (hlm. 9)

'Tidak lama terdengar bunyi berkicau di warung.Perkataan menyahuti ke sana ke mari tidak ada ujung pangkalnya' (hlm. 9)

Maksud ungkapan tersebut melambangkan situasi pembicaraan yang 
Undas Vol 14, No. 1, Juni 2018 : hlm. 48--57

ribut sekali di warung, berbicara ke sana ke sini tak ada ujung pangkalnya.

Dalam kutipan tersebut, digambarkan situasi percakapan yang seperti bunyi barucau di wawarung yang diperbandingkan dengan pandir maniti kahulu ka hili kada kasintakan hinak'percakapan atau omongan ke sana kemari tidak ada ujung pangkalnya'.

\subsubsection{Metafora Sinestesia (sinestesia meta- phoric)}

Pengkiasan lambang di dalam bahasa figuratif metafora juga dilakukan dengan memanfaatkan pertukaran nilai rasa pada pancaindra. Kiasan seperti ini biasa terjadi pada kehidupan sehari-hari pada masyarakat Banjar

Konteks 4

Nangapang mun aku lagi gagah bahari, cah asa kada kawa tu pang aku maariti liur amun sudah [tajanak bibinian bungas] (hlm.5)

'Mengapa saat masih gagah dulu, serasa tidak bisa, menahan air liur kalau sudah terpandang gadis cantik'.(hlm. 5)

Perbandingan dalam kutipan ungkapan tersebut adalah pertukaran pergeseran indra penglihat dengan indra pencium. Indra penglihat ditandai dengan frase sudah tajanak bibinian bungas 'sudah terpandang gadis cantik', bibinan bungas 'perempuan cantik diibaratkan dengan mencium makanan yang sangat lezat sehingga membuat air liur keluar tidak tertahankan lagi'.

\subsubsection{Metafora Konkret ke Abstrak (from concrete to abstract)}

Dalam menggambarkan situasi tertentu, masyarakat Banjar juga meng- gunakan konsep abstrak, seperti yang terangkum dalam kutipan berikut.

Konteks 5

Kada sing bunyian. nangkaya malaikat lalu. Marasa kalu sidin limbah kada dilawani lagi ulih Acil Amah. (hlm. 5)

'Tidak ada bersuara. Seperti malaikat lewat. Dia merasa sudah tidak dibalas lagi oleh Acil Amah.' (hlm. 5)

Metafora yang digambarkan oleh frase kadang sing bunyian dan nangkaya malaikat lalu mengiaskan situasi yang sangat sunyi seperti halnya situasi di kala malaikat sebagai utusan Sang Pencipta melewati di antara makhluk ciptaan Allah dalam hal ini hewan tertentu saja yang bisa merasakan kehadirannya. Dalam banyak kisah keagamaan khususnya agama Islam, sering digambarkan kondisi-kondisi tersebut. Sunyi (konkret) diibaratkan dengan malaikat (abstrak).

Konteks 6

Bunyi urang babisik ha lagi. Musti pang takutan jua kalu pina kadangaran [talinga rinjing] si Ahim Jaya tuh (hlm.6)

'Bunyi orang berbisik ha lagi. Mestinya takut juga kalau sampai terdengar telinga wajan si Ahim Jaya tuh (hlm. 6)'

Pada kutipan tersebut, terdapat ungkapan bunyi orang babisik yang diperbandingkan dengan talinga rinjing 'telinga panci/wajan', telinga manusia yang dikiaskan sebagai telinga atau pegangan pada panji atau wajan (alat dapur). 
Undas Vol 14, No. 1, Juni 2018 : hlm. 48--64

4.1.4 Metafora Manusia (antromorphomic metaphoric)

Metafora manusia sering kali dibandingkan benda-benda tak bernyawa seperti halnya tumbuhan, benda alam dan lain-lain.

Konteks 7

Anak si Amah ni bujur kakanakan, tapi inya sakulah. Nang kaya [lum buk pangrawit] halus haja badannya, tagal liwar padasnya. (hlm. 9)

'Anak si Utuh nih benar sih ma sih anak-anak, tetapi dia bersekolah. Seperti cabe rawit, kecil sja bentuknya, tetapi luar biasa pedasnya' (hlm. 9).

Tumbuhan digunakan untuk menyindir tetapi tidak menyakiti orang yang dituju, bahkan terlihat sekedar bercanda tetapi menyerupai keadaan yang sebenarnya. Diharapkan orang yang dikiaskan tidak tersinggung. Dalam kutipan tersebut, terdapat ungkapan nang kaya lumbuk pangrawit, halus haja badannya, tapi liwar padasnya. Bahasa kiasan ini mudah sekali dipahami karena lumbuk pangrawit adalah buah tanaman yang bisa ditemukan di halaman dan dibutuhkan setiap masak-an. Jadi sifat pedas, bentuk kecil dimanfaatkan mewakili sosok anak manusia.

Konteks 8

Pandingar nang kaya mintuha camat ha lagi. Waninya pang ikam ni. [Upung mamadahi mayang ngarannya.], tuh Laduan. Pamali, tahulah wan lawan nang tuha tu. Kalu pina katulahan.(hlm.9).
'Pendengaran seperti mertua camat lagi. Beraninya lah kamu nih. Upung mengatakan mayang sebutannya, tuh Laduan. Tabu, lah melawan yang lebih tua tu, kalau kualat'.

Pada kutipan tersebut, terdapat ungkapan upung mamadahi mayang. Upung dan mayang merupakan benda yang terkait dengan tumbuhan. Upung 'tunas' dan mayang 'bunga, kembang'. Jadi yang ingin disampaikan adalah lambang kias perbedaan kondisi yang tidak pantas untuk dilakukan karena menyangkut etika.

\subsection{Jenis Metafora Berdasarkan Struktur Pembentuknya}

Berdasarkan sintaktiknya menja-di metafora nominatif, metafora predi-katif , dan metafora kalimatif

\subsubsection{Metafora Nominatif}

Metafora nominatif menunjuk-kan posisi nomina yang menduduki fungsi sebagai subjektif, objektif, atau komplementatif.

Konteks 9

Nah, ikamam, inya maka mun tapandiri buyung mati!" (hlm.9)

'Nah, kamu pula, dia kalau terucap buyung mati, Amang Ibat menggerutu sendiri '(hlm. 9)

Dalam kutipan tersebut, terdapat ungkapan, inya maka mun tapandiri buyung mati!".Bila dianalisis, struktur ungkapan tersebut adalah sebagai berikut.

$\frac{\text { Inya maka mun } \frac{\text { tapandiri buyung mati!". }}{P}}{P}$ 
Undas Vol 14, No. 1, Juni 2018 : hlm. 48--57

'Dia kalau terkatakan buyung mati'.

Dari struktur tersebut, ungkapan buyung mati 'buyung mati' menduduki posisi pelengkap, metafora ini disebut dengan struktur metafora nominatif komplementatif.

\subsubsection{Metafora Kalimatif (Kalimat Metaforis)}

Wahab (1995) menyatakan bahwa metafora kalimat adalah seluruh lambang kias yang dipakai dalam metafora jenis ini tidak terbatas pada nomina (baik yang berlaku pada subjek maupun yang berlaku sebagai komplemen) dan predikat saja, melainkan seluruh komponen pada kalimat metaforis tersebut (hlm. 13).

Konteks 11

Bulu landau haja baluman hirang, sudah bapiragah pintarlah. Waninya umpat manyahuti pamandiran nang tuha. Banganga dahulu hanyar baucap. (hlm. 7)

'Bulu betis saja belum hitam, sudah berperilaku pintarlah. Beraninya ikut menyahuti pembicaraan orang dewasa. Menganga dahulu, baru berucap' . (hlm.7)

Kutipan tersebut merupakan tuturan metaforis yang terdiri atas beberapa kalimat, antara lain:

\section{Metafora kalimatif}

1. Bulu landau hajabaluman hirang, S P1 sudah bapiragah pintarlah. $\underline{P 2}$

'Bulu betis saja belum hitam, sudah berlagak pintar'

\section{Metafora predikatif}

2. Banganga dahuluhanyar baucap. $\mathrm{S}$

Ket /FV -Fadv, V/ F

'Membuka mulut dahulu, baru mengucap.'

Ket /FV -Fadv, V/ F

Metafora kalimatif yang tampak pada kedua ungkapan tersebut adalah sebagai berikut. Pada frase Banganga dahulu subjek merupakan verba bukan nomina.

Konteks 12

Pandinaran nang kaya mintuha camat ha lagi. Waninya pang ikam ni. Upung mamadahi mayang ngaran-nya, tuh Laduan. pamali, tahulah wan lawan nang tuha tu.Kalu pina katulahan.(hlm. 9) .

Perkataannya seperti mertua camat lagi. Beraninya kamu ini, Upung mengaku mayang istilahnya, tuh Ladun, tabu, tahukah dengan melawan yang tua, kalau nanti kuwalat' (hlm. 9).

Pada kutipan di atas, terdapat ungkapan upung mamadahakan mayang 'Upung mengatakan/mengaku mayang' yang memiliki konstruksi metafora kalimatif sebagai berikut.

\section{Upung mamadahakan mayang}

Metafora yang terdapat dalam ungkapan tersebut adalah metafora kalimatif. Metafora tersebut baru bisa dipahami secara keseluruhan dan bukan sepotong-sepotong. 
Undas Vol 14, No. 1, Juni 2018 : hlm. 48--64

\section{PENUTUP}

\subsection{Simpulan}

Berdasarkan hasil analisis dan pembahasan, diperoleh simpulan sebagai berikut. Dilihat dari jenisnya, metafora diklasifikasikan menjadi 1) metafora kehewanan $(2)$; 2) metafora sinestesia $(1)$; 3) metafora konkret ke abstrak (2 ) 4) metafora manusia (2). Dilihat dari sintaktiknya metafora dapat dibedakan menjadi 1) metafora nominatif (subjektif dan komplementatif) dan metafora kalimatif

\subsection{Saran}

Penelitian mengenai metafora memberikan manfaat yang besar bagaimana memahami fenomena kebahasaan di sekitar kita. Oleh karena itu, masukan saran dari pembaca akan membantu penulis demi pengembangan kajian selanjutnya.

\section{DAFTAR PUSTAKA}

Haley, Michael, C. (1980). “Concrete abstraction: The linguistic universe of metafor" dalam Marcin K. Ching dan Michael hale. 1980. Linguistic Perspective on Literature. London: Routledge \& Kegan Paul.

Jamzaroh, Siti., Wahdani, Siti Alfa, Laila. (2017) "Nilai-nilai kearifan dalam paribasa urang Banjar. "Salingka, hal, Padang: Balai Bahasa Sumatera Barat.

Lakoff, G \& Johnson, M., (2003). Metaphors we live by $(2 n d)$, Chicago: The University of Chicago Press.
Karsana, Deni. (2017). "Metafora dalam bahasa Kaili: Cerminan rara pandang etnik Kaili." (makalah). Prosiding Kolita 15. Jakarta: Universitas Atmajaya. ISSN: 2549-810X.

Kridalaksana, Harimurti. (2008). Kamus linguistik. Jakarta: Gramedia Pustaka Utama.

Prayuda, (2013). "Metafora sebagai nasihat dalam horoskop Jawa: Studi Linguistik" Antropolinguistik. Proceeding International Seminar Lamas Maintainance and Shift III. Semarang: Master Program in Linguistik Diponegoro University in Collaboration with Balai Bahasa Jawa Tengah. ISNN: 2088-6799

Rahyono, F.X (2012). Studi makna. Jakarta: Penaku.

Srinengsih, (2016) . "Makna idiomatik dalam ungkapan bahasa Banjar." Undas. Banjarmasin: Balai Bahasa Kalimantan Selatan.

Subroto, Edi. H.D. (2011). Pengantar studi semantik dan pragmatik. Surakarta: Cakrawala Media.

Suryanata,T Jamal, (2005). "Julak ahim". Galuh, sakindit kisdap Banjar. Ban-jarmasin: Grafika Wangi

Suryatin, Eka. (2013)."Macam-macam flora dan fauna dalam ungkapan bahasa Banjar" Undas. 
Undas Vol 14, No. 1, Juni 2018 : hlm. 48--57

Banjarmasin: Balai Bahasa Suwandi, Sarwiji. (2008). Serba

Kalimantan Selatan.

Wahab, Abdul (1995). Isu linguistik: pengajaran bahasa dan sastra. Surabaya : Airlangga University Press. linguistik : Mengupas pelbagai praktik berbahasa. Surakarta: LPP dan UPT Penerbitan dan Pencetakan UNS (UNS Press) Universitas Sebelas Maret. 